\title{
Study on the Students Moral Accomplishment Promoted By College Ideological and Political Theory Course
}

\author{
Lihua Wang \\ Liaoning Economic Management Cadre Institute Shenyang, Liaoning 110122
}

261146665@qq.com

Keywords: Colleges and universities; Ideological and political theory course; Students; Moral cultivation

\begin{abstract}
To strengthen the moral accomplishment of students in higher vocational schools is the quality education requirement, conforming to the core content summarized in 18th congress party to set high moral values and to cultivate people. Ideological and political course teaching is the main channel for students to accomplish morality. To fully take advantage of classes, accurately understand the ideological and political thoughts of students, focus on their thought structure; pay attention to the teaching content as well as teaching methods reform, constitute coordinated teaching mechanism, realize the calling to arm the mind with theory, practice morality and organize thinking ability.

Moral accomplishment is a good virtue known in China, which is the target of higher vocational school to cultivate talents. Ideological and political course is the main channel of ideological and moral education in higher vocational schools, which can be deemed as an important course of higher education. It is implemented under the guidance of theory and takes socialist core value system as the mainline, aiming to cultivate their moral quality. It combines problems which students are interested in while teaching and highlights theoretical as well as comprehensive and practical education based on deep thought and powerful theoretical support so as to cultivate students' morality and law consciousness to make them become qualified constructor for national rejuvenation.
\end{abstract}

\section{Teachers of Ideological and Political Course Should Keep Pace with Time and Deeply Understand Teaching Material}

The teaching material for ideological and political course has been modified 6 times since its publication in 2006. Every modification keeps pace with the spirit of time and will demonstrate the innovation of communist party's theoretical lines. The latest modification is more proper for teaching requirement, which comprehensively collects the suggestions of users and adopts a glittering array of solutions put forward by teachers. At the same time, it also reflects the spirit of Decisions on deepening the reform of cultural system and promoting the great development and prosperity of socialist culture, which also shows the ideas of president Hu Jintao presenting in 90th anniversary of the founding of CPC and memorial meeting of the 100th anniversary of Xinhai Revolution as well as the 18th congress party spirit. As college teachers, they have to be familiar with the modification and present the results. Before the school commencement of 2013, an explanation meeting of national ideological and political course was held in various regions, hoping to convey the information of modified contents in the first time and help they transmit the communist spirit. What's more, they have to deeply understand the teaching materials because the content is stable, powerful and targeted. Furthermore, the research group of material modification should listen to and organize the suggestions put forward by students and teachers to improve the quality and strengthen the scientific base. Last but not least, teachers have to totally understand why the contents are changed and why did they change from this perspective and if it is proper. Only in this way, can they technically imbue students with the latest communist ideas and help students to understand. 


\section{Ideological and Political Teachers Should Comprehensively Develop Their Abilities}

In order to face the needs of new development trend, and cultivate students' moral achievement, ideological and political teachers should improve their teaching ability, researcher ability and convincing ability.

Teaching Ability Improvement Needs Role Transition. Everyone acts different roles and as teachers, they have to improve their teaching ability and transit roles in knowledge, position, thoughts and actions. To begin with, knowledge transition: Han Yu once said, You impart knowledge and solve doubts and preaching. Teacher should systematically organize knowledge and convey this information to students. In addition, they have to understand the political and historical knowledge, refer to the history to solve modern problems and know the solutions to solve problems. What's more, they should pay attention to the relation between old and new knowledge, consolidate old knowledge and explore new knowledge. In every class, they should review the theoretical knowledge, refer to materials, find proper teaching cases and understand the development direction. Furthermore, they should be able to summarize and give a good explanation to abstract knowledge and find out difficulties. Teachers are also expected to divide key points and points which are not that important and clear it in class so as to help students to remember the key. Secondly, position transition: teachers are helpers, coordinator, valuator, teaching activity designer and study environment developer of the learning process, so they have to encourage students to positively think and guide them to learn. Thirdly, thoughts transition: to understand students is the necessary premise of carrying out ideological and political education. Professor have to firstly know the students number and female-male percentage and remember the names of students. When students realize that their teachers know their name, they will have a feeling of being respected and happy and are willing to build a good relation with them. Teachers should also strengthen connections to students and understand them, think from their perspective, which is beneficial to achieve an excellent teaching result. Fourthly, actions transition: actions of teachers will create a big effect on students. Confucius once said if the ruler himself is upright, all will go well even though he does not give orders. But if he himself is not upright, they will not be obeyed if he gives orders. From this, we can say that teachers should be upright and set a good example. Of course, the teaching ability of ideological and political teachers is a organic unity. Besides roles transition, they have to improve the ability to communicate and demonstrate and strengthen both their internal and external ability.

To Improve Research Ability, Teachers Have to Read a Lot and Think a Lot. The research ability is an important means to check the academic result and important materials to compete for titles as well as the final demonstration of academic achievement. In order to improve the research ability of teachers, we have to innovate their thoughts, set the important status of ideological and political course. In addition, teachers have to realize the philosophy of being a person and teach them proper thinking ability, healthy living style so as to lead them into successful paths. Nowadays, the development trend is unpredictable and scientific technology changes rapidly, which will trigger influence on the concepts of students born after 1990 in higher vocational schools. So, teachers have to understand the features of times and explain the teaching based on new theories. During the teaching process, we have to fully play the role of students and adopt interactive teaching methods to exchange ideas and ignite their passion. In addition, teachers should summarize the advantages as well as disadvantages because every point teacher puts forward in class may trigger new ideas. However, students themselves should also reflect and summarize to create a unique teaching method and be brave to do research. At present, there is a glittering array of research topics from all levels yet lots of ideological and political teachers do not have innovative points and lose confidence. Actually, the reason why they fail because their ideas as well as research directions need to be innovated. Under such circumstance, teachers have to read a lot and think a lot. Based on this, teachers can refer to the previous history and find out why they fail. By researching on the seminars, they can improve their research ability and help students accomplish morality.

Convincing Ability Improvement Needs Quality and Insight. Ideological and political 
teachers have lots of opportunities to discuss with students. Therefore, they have to be equipped with solid political quality. In addition, teachers should have advanced thoughts, love our country and party with respect and confidence, who practice what they preach. When students ask them about questions, they should answer fluently so they will consider their teachers as rich in knowledge. In addition, if students put forward a hot topic, they are able to do simple introduction. Moreover, if they have some sharp questions, teachers should also be able to use a political mind with full preparation. By the way, teachers should have courage and insight. If they cannot answer the questions students put forward in class, they can throw out their ideas and lead students to talk about it. And if teachers do not meet that kind of questions before, they can ask students to carry out a deeper communication after class. However, teachers should practice what they preach, and contact students once they find the answer and put forward their ideas which are accessible so as to correct students. After lots of cases, teachers will improve their abilities to analyze sensitive topics, which is beneficial to improve the morality accomplishment of those who have radical thoughts.

\section{Innovative Teaching Contents of Ideological and Political Course}

Teaching contents should be progressed along with the development of society, which conforms to the education rules. As a special production, the contents of ideological and political education should be updated along with the changes of the society so as to keep pace with times. To being with, we have to arm our minds with theory. Relevant teachers should deeply dig into the basic theories of Marxism and meanwhile explore into emerging problems of modern construction so as to keep pace with the current condition and combine the hot topics to solve the problems put forward by students from a totally new perspective. In addition, teaching design should take into consideration the course positioning, teaching theme, difficult points so as to timely adjust and better demonstrate the whole function of this course. Furthermore, during the teaching process , teachers have to creatively design and organize the teaching to have unique features based on the characteristics of students and strengthen the effectiveness of the society. Take the Ideological \& Political Education and Fundamental Laws as an example, the latest modified one added two sections including the health psychology of college students and career development. And, chapter three, seven, eight explains the two sectors so that teachers can reasonably arrange the teaching contents and pay more attention to solving difficult points. By adjustment and supplement, the teaching contents will be more proper for morality achievement as well as employment needs, because it is practical, which can stimulate the passion of students to learn and improves the teaching effect. Secondly, practice will test morality. In order to strengthen the teaching effect of ideological and political education, we have to cultivate students' consciousness on the society as well as reality. Based on this, students improved their social responsibility, and ability to analyze, solve problems and innovate. The ideological and political education in our school adopts 30\% practical teaching, including debate, lecture, hot topics discussion, social survey, exploration and campus celebrity election eat to enrich class teaching. Besides, if the teaching requirement and social practice target is the same, students can implement targeted social practice, which can help to strengthen the teaching direction, optimize the effect of self-management, refine the assessment index of practical classes and check the morality performance. Last but not the least, we can comb the thoughts to rich campus activities, improve morality and accomplish their moral cultivation.

\section{Methods to Innovate Ideological and Political Course Teaching}

To improve the morality accomplishment, we have to firstly pay attention to the innovation methods. After the reform and opening up, people's life has changed a lot and single child does not have rational thinking and scientific judgment on political issues. They question the beliefs of communism with obvious benefits-oriented ideas and a confused mind. Only by flexibly taking advantage of various means can we strengthen the teaching effect. Firstly teachers should be fully prepared and positively teach because they are responsible for maintaining and organizing and students pay much attention to them while their condition will directly affect the learning efficiency. 
Secondly, lots of higher vocational schools adopt multi-media teaching to directly show the contents so as to avoid visual fatigue. Meanwhile, they carry out topic lectures with good effects and class discussion is also a good way. However, we have to inform students of the topic in dance so as the let them prepare and give rich contents. By the way, we can take the action of positively joining in as reference of final assessment. Diesterweg focuses on cultivating students' language ability and is against independent teaching. He pointed out that teachers should pay attention to the pronunciation, tones, contents and explanation ways so as to help them cultivate clear language and logic thinking ability to understand the teaching materials. Actually, students like that kind of interactive teaching methods, which trigger students' initiative as well as passion and cultivate their ability to recognize problems, analyze problems and speak. More importantly, students can exchange ideas, which can help them to have a more profound and comprehensive understanding. Of course, we can adopt class lecture, debate and dramas to teach, to create different and unique styles. However, that have to focus on the teaching art, which means that teachers have to obey the education rules to creatively adopt methods to create beauty and let students learn in a happy mood.

\section{Evaluation System for the Innovative Ideological and Political Course Teaching}

Morality is the basic quality of human beings in this mundane world. Excellent morality accomplishment is the result of constant learning. Ideological and political course is practical, which focuses on the unity of knowledge and practice. obeying rules and transferring knowledge into internal quality. The assessment of ideological and political course should adopt the combination of regular performance and final exam. Regular performance includes attendance, class interaction and speech. Teachers can record the attendance and their daily work and give them an assessment interacting with the final exam result. This kind of scientific and effective assessment will help with the improvement of students.

All in all, colleges teachers of ideological and political education should constantly summarize and carry out reform as well as innovation on teaching, and meanwhile focus on the target and time of teaching contents. What's more, they should also adopt flexible teaching contents to make the teaching contents interesting to improve the passion of students and promote the effective promotion of ideological and political course teaching.

\section{References}

[1] Guidance on further strengthening and improving the ideological and political education suggested by central committee and the State Council [M]. Beijing: China Renmin University Press, 2005.

[2] Yu Yuhua. Thoughts on the course positioning, features and teaching conditions of Ideological\&Moral Cultivation and Fundamentals of Law [J]. Ideological \& Theoretical, Education July, 2013.

[3] Zou Qun, Wang Qi. Modern Education [M]. Dalian: Press of Liaoning Normal University. December 2012

[4] Yu Cuihong, Cao Jianzhou. Several thoughts on the teaching of Ideological\&Moral Cultivation and Fundamentals of Law [J]. Journal of Inner Mongolia Polytechnic University (Social science edition) January 2009 